\title{
DESIGNING LIFE SKILL - BASED ENGLISH READING MATERIALS FOR SECOND GRADE STUDENTS OF SMA NEGERI 1 PRINGGASELA
}

\author{
Ari Saputra $^{1}$, Sutarman $^{2}$, Syamsurrijal $^{3}$ \\ arisaputra1985@gmail.com ${ }^{1}$, sutarmannarmada@gmail.com ${ }^{2}$, \\ rijalhalilintar@gmail.com ${ }^{3}$ \\ Universitas Gunung Rinjani, Universitas Bumigora
}

\begin{abstract}
This research aims to: developing life skill-based English reading materials design for the second grade students of SMA NEGERI 1 PRINGGASELA. The design used in this research is report design by using R\&D ( Research and Development ) approach. The subjects of this research are the second grade students of SMA Negeri 1 Pringgasela in academic year 2016/2017. There are 35 students. In collecting data, the researcher uses two steps. First, the researcher distributed questionnaires into the students. Second, the researcher gathers data for conducting evaluation, opinion and suggestion from an English Teacher of SMAN 1 Pringgasela and an expert of designed materials. All responses and comments to the open questions were reviewed and grouped into some meaningful categories as they provide useful information for revising the product. To determine the readability level of the texts used in new developed reading materials, the following are the categories of readability level and reader grade level according to Flesch Readability East Formula and Flesch-Kincaid Grade Level. Scores between 90.0 and 100.0, considered easily understandable. Scores between 60.0 and 70.0, considered easily understood. Scores between 0.0 and 30.0, considered easily understood. The final product of the materials consists of a course material of Life Skill Based English Material and a teacher's manual. Whole Language Reading provides rich input of reading strategies, variety of topics, concepts, texts, activities, tasks, and evaluations. Using this material makes reading more holistic and meaningful as it provides integration across language skills and subject areas. Educational institutions need to provide a rich learning environment with a variety of reading sources, print and digital to provide opportunities for students to choose and determine reading materials that suit their needs.
\end{abstract}

Keywords: Life skill, Reading

\section{A. INTRODUCTION}

Classroom activities not only give students the knowledge, but classroom activities should support students to make life to be valuable. Life should be valuable means that knowledge student that have been gotten can be used for solving problems and implemented in life. Learning activities in classroom should not be directed only for introducing, remembering and comprehending knowledge. Graves (2000:152) stated that students activities should allow students to problem solve, discover 
Journal on Language and Literature Vol. 6 No. 2 June 2020

analyze, so that students will be engaged and students will use the language. Learner should use the knowledge to be more practical and helpful in their life next.

The mastering English well is influenced by some factors as follows, motivation, teacher, facilities, media, materials, and methods. Moreover, according to Dubin and Olshtain (1986:27-32), there are five basics components of the program that should be examined : (a) the existing curriculum and syllabus, (b) the material in use, (c) the teacher population, (d) the learners , and (e) the resources of the program. Based on the explanation above, the materials is the one of the important factors that has a significant role in the achievement of the aims of learning English well.

The knowledge that supports the life is called life skills. Life skills can be gotten by learning. Therefore, the learning activities in classroom should be designed particularly to produce life skilled students. According to Richard (2001:188), the goals of materials is to make classrooms activities as meaningful as possible by relating classroom activities to the real world, and by fostering real communication among the learners.

Life skill-based materials may help teachers and students to make a learning situation in classroom more attractive and interesting. It also expected to help the aims that school can produce the life skilled students. Students also facilitated to build up their creativity and the ability to solve the life problems. According to Graves (2000:153), students' activities should help students develop specific skills and strategies, so that students can transfer skills to other learning situations. Life skills include a wide range of knowledge and skill interactions believed to be essential for adult independent living (Brolin, 1989). At present, many students with handicaps have special needs that are not being met.

Richard Francois (1999:90) states that one of the most critical life skills a human being must be posses in order to survive in the modern life is the ability to read. Being able to read opens the mind to limitless possibilities. Reading allows individual significantly enlighten themselves with the exploration of new worlds and the exchanging of ideas. The present researcher see the capability of reading skill in the students are still low. That is like said by Mr. Merdana, M.Pd the teacher English 
Journal on Language and Literature Vol. 6 No. 2 June 2020

of SMA Negeri 1 Pringgasela . so the present researcher attempt to investigate Designing life skill-based English reading materials for the second grade at SMA Negeri 1 Pringgasela in the academic year 2018/2019.

Factors that influenced the success of English language learning are the existing curriculum and syllabus, the usage material, the teacher population, the learner, and the resource of the program. Materials that used in learning activities have big role in the achievement of the aims of the learning process. Learning materials designed by considering existing curriculum and syllabus that being used at the time.

Nowadays, materials developers use many approaches to be their basic of the materials. Materials for Junior high school should be interesting, easy to understand, attractive to make learners be interested in learning English. Interesting materials can be students centered and life skill-based.

\section{B. RESEARCH METHOD}

This research was applied research and development. According to Sugiyono (2009:407), research and Development is a research method used to produce product and to examine the effectiveness of product.

Research and development (R\&D) activities comprised creative work undertaken on a systematic basis in order to increase the stock of knowledge, including knowledge of man, culture and society, and the use of this stock of knowledge to devise new applications.

Basic research is defined as systematic study directed toward fuller knowledge or understanding of the fundamental aspects of phenomena and of observable facts without specific applications towards processes or products in mind. Applied research is defined as systematic study to gain knowledge or understanding necessary to determine the means by which a recognized and specific need may be met. 
Development is defined as systematic application of knowledge or understanding, directed toward the production of useful materials, devices, and systems or methods, including design, development, and improvement of prototypes and new processes to meet specific requirements.

Research and development is a type of research that is done to bridge the gap that often occurs between educational research and educational practice. Therefore, this type of research is often used to solve practical problems in education. For example, it is used to develop and validate educational products and procedures, which are systematically field-tested, evaluated, and refined until they meet specified criteria of effectiveness or quality standard (Gall et al., 2007, 589). The steps of this process are usually called the R\&D cycle, which consists of studying research findings related to the product to be developed, developing the product, field testing and revising the product until the product meets its defined objectives (Borg \& Gall, 1983, 772-775).

This research will be conducted at SMAN 1 Pringgasela in the academic year 2018/2019 as a respondent. Reasearcher will be focused on the second grade students of SMAN 1 Pringgasela.

The respondent of need analysis was English teacher and students of the second grade in SMAN 1 Pringgasela. The researcher will use the respondents to get information about learners' needs in learning English and to understand the characteristics of learners in SMAN 1 Pringgasela .

To design suitable Life Skill-Based English learning materials for students in SMAN 1 Pringgasela, researcher uses instruments. The instruments are questionnaires. According to Wilson and McLean (1994) in Cohen Louis et al (2007:317), questionnaire is widely used and useful instrument for collecting survey information, providing structured, often numerical data, being able to administer without the present researcher, and often being comparative straightforward to analyze. Therefore, the researcher used questionnaire to get an information about leaning needs and an in the next, the materials can be appropriate for the targets. 


\section{Oumanitatis}

Procedure of Development is arranged to make the design systematic and easier. According to Sugiyono (2010:209), there are several steps in doing research and development to produce product and to trial the effectiveness of the product. The steps are (a) identifying the problem, (b) collecting data, (c) product design, (c) product validation, (d) design revision, (e) product trial, (f) product revision, (g) usage trial, and (h) mass production.

The graphic development procedure is as follow:

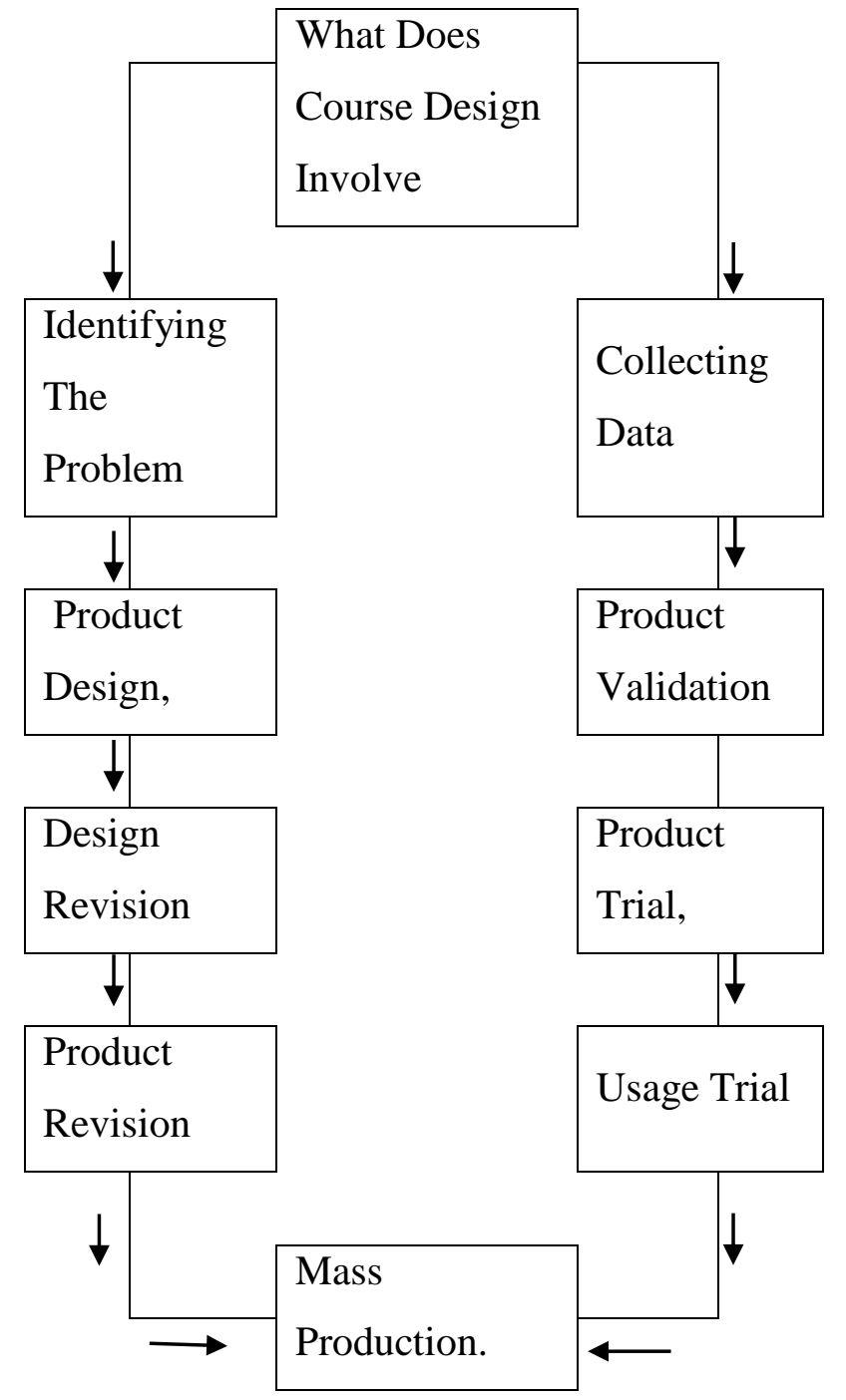

Picture 2.1: Graphic Development Procedure 
In collecting data, the researcher uses two steps. First, the researcher distributed questionnaires into the students. Second, the researcher gathers data for conducting evaluation, opinion and suggestion from an English Teacher of SMAN 1 Pringgasela and an expert of designed materials.

Data from questionnaires were collected from the rating scales and the categorical items in simple tally and presented in the form of frequency tables to show the percentages of cases in each scale and category. All responses and comments to the open questions were reviewed and grouped into some meaningful categories as they provide useful information for revising the product.

To determine the readability level of the texts used in new developed reading materials, the following are the categories of readability level and reader grade level according to Flesch Readability East Formula and Flesch-Kincaid Grade Level.

a) Score 90-100 $\rightarrow$ very easy

b) $80-90 \quad \rightarrow$ easy

c) $70-80 \rightarrow$ fairly easy

d) $60-70 \quad \rightarrow$ normal

e) $50-60 \quad \rightarrow$ fairly difficult

f) $30-50 \quad \rightarrow$ difficult

g) $00-30 \quad \rightarrow$ very difficult

Scores between 90.0 and 100.0, considered easily understandable by 5th grader. Scores between 60.0 and 70.0, considered easily understood by 8th \& 9th graders. Scores between 0.0 and 30.0, considered easily understood. Then, in effectiveness testing of the new developed reading materials, independent sample ttest was used to compare students' reading comprehension scores, both in control and experimental groups. A significant difference is found when the significant value is lower than .05 .

\section{FINDINGS AND DISCUSSION}

How are the key features of whole language applied in teaching reading in this entitled Life Skill Based English Material. First, it emphasis on the comprehension 
of the whole passage, at the same time, gives consideration to the study of grammar, vocabulary, and content. Second, students are encouraged to integrate oral and written English in learning activities by discussing and writing frequently about the texts they read. Through these activities, they can improve their language skills. Third, students are encouraged to read different texts in Religion, Literature, Mathematics, Science, Social Studies, etc. as language (English) does not exist in a vacuum, but exists in all aspects of human life. Fourth, teacher makes full use of contexts to cultivate students' language ability by providing more chances for the students to do some contextual comprehension practice by questioning, predicting, discussing, analyzing the text, etc. Fifth, students cannot be assessed by using tests as the only criteria to measure their reading achievement. Teacher should also evaluate students' homework and reading reports. Sixth, students are encouraged to work collaboratively on their tasks and projects. Teacher creates a good learning atmosphere in which students have the opportunity to state their own views, to hear from others, to discuss their ideas, and to hone their argumentative skills. This can form a lively environment of language learning.

Life Skill Based English Materials have some strengths and limitations. Here are some of the strengths. First, entitled Life Skill Based English Material is designed to help students improve their reading comprehension skills and higher order thinking skills needed to achieve a college-level reading proficiency. entitled Life Skill Based English Material is also appropriate for helping students develop their knowledge of other disciplines because it integrates content across the subject areas. Second, entitled Life Skill Based English Material gives emphasis on the comprehension of the whole passage, and at the same time, gives consideration to the study of grammar, vocabulary, and content. Third, students are encouraged to integrate oral and written English by discussing and writing frequently about the texts they read. Through these activities, they can improve their language skills. Fourth, entitled Life Skill Based English Material makes full use of contexts to cultivate students' language ability by providing more chances for the students to do some contextual comprehension practice by questioning, predicting, discussing, analyzing 
Journal on Language and Literature Vol. 6 No. 2 June 2020

the text, etc. Fifth, students are encouraged to work collaboratively on their tasks and projects. This creates a good learning atmosphere in which students have the opportunity to state their own views, to hear from others, to discuss their ideas, and to hone their argumentative skills. This can form a lively environment of language learning. This study also has several limitations. First, not all the findings of need analysis can be accommodated in Life Skill Based English Material. For example, not all the topics required by the students can be presented in Life Skill Based English Material. Second, in this study, the researcher did not examine the effectiveness of Life Skill Based English Material in improving students' ability in other language skills such as listening, speaking, or writing.

Besides the discussions above, it was found also in this study that the students apply some reading strategies while they use the English life skill based materials.

The data from questionnaire shows that the students employed some strategies as follow:

\section{a. Memory Strategy}

Memory strategy is the strategy which actually helps learners store in their memory and what they read in the new language, enlarging their knowledge base and also enables learners to retrieve information from memory when they need to use it for comprehension reading or production (Oxford, 1990:58).

The types of memory strategy used in a high level are associating/elaborating strategy (In reading English text, I think the relationship between what I already know and new things I learn in English) and Using imagery strategy (I use new English words in a sentence so I can remember them) while Placing new word into context strategy was used in a medium level.

Those data indicate that high and middle achiever students always associate the materials that they read as their background knowledge with the new reading materials in comprehending an English text. They connect the new information and the old one to recall their knowledge which is kept in memory. It is in line with Oxford (1990:60) who states that in associating/elaborating strategy, a reader 
Journal on Language and Literature Vol. 6 No. 2 June 2020

should involve associating new language information with familiar concepts already in their memory and naturally, these associations are likely to strengthen comprehension, as well as, making the material easier to remember. O'Malley \& Chamot (1993:21) argue that association/elaborating strategies deal with the links which are similar to the more often been referred.

This is also related to Cohen \& Aphek (1980, in Wenden and Rubin, 1987:28) who found that a generally high success rate for recall of words that were learned was through associations.

The second type of memory strategy which is always used by high and middle achiever students is imagery strategy. It indicates that high and middle achiever students always imagine the words that they read. This strategy also helps readers to remember by creating a mental image in their memory. According to Oxford (1990:61), a good way to remember what has been read in the new language is to create a mental image of it. In addition, Oxford explains that a reader is able to make mental images of objects like house or tree, or descriptive adjectives like wide or tall to be more concrete.

The use of imagery strategy also enables a reader to connect the new information in visual concepts through memory. Wenden and Rubin (1987:77) define imagery as a process of relating new information to visual concepts in memory via familiar easily retrievable visualization, phrases, or location. Jennings (2006:280-1) who studied about the use of imagery strategy for a fourth grader student has found that the activity made student interacts with the text, and his comprehension of the story improved dramatically. This strategy also facilitates the students to overcome their poor comprehension and found silent reading difficult. Garnasih (2006) investigated reading strategies most frequently employed by the high and the low proficiency readers of third grade students in SMPN 4 Malang was found that the direct reading strategies most frequently employed by the high proficiency students among others repeating, translating, and using references for understanding, using imagery, practicing naturistically, structured reviewing, recognizing and using patterns. 
Journal on Language and Literature Vol. 6 No. 2 June 2020

Blachowicz \& Ogle (2008:150-1) state that an important aspect of reading is creating visual images in one's head as one reads. Many researchers have found this ongoing mental activity as a characteristic of good readers.

Blachowicz \& Ogle (2008) explain some previous researchers who have studied about creating mental images among others Durrell (1956), Grambrell and Almasi (1996), and Sadoski and Paivio (2004). The study found that the attention to readers' imagery has proven valuable. When readers create images from words, they are clearly engaged by the author and the text has come alive.

The data also show that most of higher and middle achiever students in this study prefer to use memory strategy because it helps them in understanding an English text. Barclay (1973) \& Sachs (1974) claim that one important and common means of chunking is to employ imagery to remember; there is a substantial literature demonstrating the unsurprising fact that our recall of particularly graphic sentences that we have heard or read is more likely to be related to scenes that we image form descriptions provided by the words than to the words themselves (Barclay, 1973, Sachs, 1974, in Smith, 2004:272).

Those arguments above explicitly suggest that the use of memory strategy, especially for imagery in reading English text encourages the students to understand an English text completely. Moreover, high and middle achiever students also used placing new words into context strategy in a medium level which indicated that they just sometimes used the new words in creating a sentence. According to Oxford (1990), this strategy involves placing new words or expressions that have been read into a meaningful context, such as a spoken or written sentence, as a way of remembering it. In such cases, it helps for learner to create their own context.

The data from table 4.1 also reveal that low achiever students only sometimes used memory strategy in comprehending reading materials. In the other words, it can be argued that they just sometimes connected the new information that they read with their last knowledge to comprehend a text. Based on 
Journal on Language and Literature Vol. 6 No. 2 June 2020

the data from high achiever and middle achiever students, the English teachers are recommended to explore their teaching method especially for teaching reading. Some strategies that might be used to increase the students' reading comprehension are: (1) helping students to enjoy and value reading, including making sure there is an attractive extensive reading program, (2) understanding what reading involves, how language conveys meaning and how texts are put together, (3) finding out what the students can and cannot do, and working out program to develop the skills they lack and (4) preparing the students to undertake the task (Nuttal, 1996:32-3).

\section{b. Cognitive Strategy}

Cognitive strategy is useful for understanding and recalling new information. Cognitive strategy is also important to function in the process of becoming competent in using the new language (Oxford, 1990:8). O'Malley \& Chamot (1990:16) explain that in a cognitive theory of learning, second language acquisition cannot be understood without addressing the interaction between language and cognitive.

The data from cognitive strategy above show that high achiever and middle achiever students employed cognitive strategy in a high level which. It means that high and middle achiever students always use cognitive strategies when reading English text. Moreover, the low achiever students used cognitive strategy in a medium level which indicated that sometimes they used cognitive strategy in trying to comprehend English text.

Some types of cognitive strategies which were used in a high level by high achiever students as follows: repeating (3.8), recognizing and using formulas and patterns (3.8), skimming (4.3), scanning (3.7), using resources for receiving messages (3.8), translating (3.8) and taking notes (3.5). Besides that, they also employed Practice naturalistically (3.2), Analyzing expression (2.8), Reasoning deductively (3.4), Summarizing (2.7), and Highlighting strategies (2.7) in a medium level. 
Journal on Language and Literature Vol. 6 No. 2 June 2020

The types of cognitive strategies which were used by middle achiever students in a high level are: repeating (4.5), reorganizing and using formula and pattern (3.5), skimming (4.1), scanning (3.5), using resource for receiving messages (4.7), analyzing expression (4.5) reasoning deductively (3.8), and highlighting (3.9). In the medium level, the strategies which were employed as follows: practice naturalistically (2.9), translating (3.1), taking notes (3.3), and summarizing (3.1).

Some types of cognitive strategies which were used by low achiever students in a high level as follows: repeating (3.9), skimming (3.7), scanning, and (4), using resource for receiving messages strategies (4.4). They utilized analyzing expression (3), reasoning deductively (3.1), translating (2.5), and highlighting (3.2) in the medium level. The reading strategies which were rarely or never used by lower achiever students are reorganizing and using formula and pattern (2.2), practice naturalistically (2.1), taking-notes (2.3) and summarizing (2). The data above indicated that high, middle and low achiever students always read an English text more than once for understanding or comprehending a text. They need repeating strategy when reading as stated in question number 4 (I read the text more than once to understand it more completely). The use of this strategy is effective to increase students' reading proficiency as stated by the US National Reading Panel (NRP) that repeated oral reading was effective in improving reading proficiency (NRP, 2000 in Harrison, 2004:113). It is also in line with the study of Therrien (2004) about fluency and comprehension gains as result of repeated reading which reports that repeated reading to an adult was more effective than repeated reading to a peer, both in building fluency and in building comprehension (Therrien, 2004, in Walpole \& McKenna, 2007: 71).

Dowhower $(1987,1994)$ states that the use of repeated reading enable the students to read more accurate. In addition, Dowhower argues that students' reading speed increases and becomes more expressive (Dowhower, 1987, 1994, in Jennings et all., 2006: 222). Repeating strategy also can be used in highly innovative ways, is actually essential for all four languages skills and virtually 
Journal on Language and Literature Vol. 6 No. 2 June 2020

always includes some degree of meaningful understanding (Oxford, 1990:70).

Some activities which are suggested to employ repeated strategy are (a) read to get drift or the main ideas, (b) predict, (c) read for detail and (d) write down questions.

Recognizing and using formulas and patterns (I try to find the pattern in English from the text) also becomes a popular strategy for high and middle achiever students to comprehend an English text. Moreover, the low achiever students just employed it in a low level (rarely or never). It indicates that the High and Middle achiever students always try to find out and understand the formulas and patterns when reading. This strategy might be employed by a reader to get meaning from a difficult text in terms of sentences structure because every sentence has different formulas and patterns. Oxford (1990:71-2) states that using recognizing and using routine formulas and patterns in the target language greatly enhance the students' comprehension and production in reading. It helps them to understand patterns when they read. In this case, low achiever students should be taught about how to make meaning and get meaning from an English text by using reorganizing and using formulas and patterns.

The other strategies which are always employed by high, middle and low achiever students as follows: skimming, scanning and using resources for receiving messages. The use of skimming strategy in a high level indicates that students always try to get general information first then reread all the sentences from the text to find the specific information. Anderson (1991) defines skimming as a type of strategy employed by a reader to look for a general understanding (Anderson, 1991, in Koda, 2005: 208).

Grabe \& Stoller (2002:13) state that skimming strategy involves, in essence, a combination of strategies for guessing where important information might be in the text, using basic reading comprehension skills on those segments of the text until a general idea is formed. Skimming strategy is significant for readers because it enables them to search the main ideas/general sense that the readers want to get across (Oxford, 1990:80, Silberstein, 1994:11), glancing 
Journal on Language and Literature Vol. 6 No. 2 June 2020

rapidly through a text to determine its gist (Nuttal, 1996:49; Nurhadi, 2005:97; Mikulecky \& Jeffries, 1996:132).

You skim to get the general sense of a passage or a book. How do you skim?

You should ready only the words that will help you get the sense of the text.

The following passage shows that you should read-read the first sentences or paragraph quietly carefully. The beginning often contains general information about rest of the text. If the text is too long, you might read the second paragraph (Mikulecky \& Jeffries, 1996: 132-3).

The all information above emphasize that a good reader should employ skimming strategy in reading to comprehend an English text quickly. In addition, the data from table 4.2 indicate that high, middle and low achiever students always try to find out the specific information from the text when reading. They read all the text meaning comprehensively. The use of scanning strategy is appropriate with Oxford (1990), Nuttal (1996) who state that scanning strategy is used to search for specific details of interest information from a text (Oxford, 1990:80, Nuttal, 1996:80), and it can be employed to look for specific words that would support the author's arguments (Silberstein, 1994:11; Mikulecky \& Jeffries, 1996:15). This strategy is also useful for students who read an article or English text book.

The importance of using scanning strategy in comprehending reading materials is also emphasized by Richard \& Schmidth (2002:467). They state that the readers may use scanning strategy to read through a chapter of a book as rapidly as possible in order to find out information about a particular date, such as when someone was born. Some stages of scanning which are suggested by Nurhadi (1987:120) in reading a book are: (a) read the table of content and introduction, (b) analyzing briefly about the background of writing the book, (c) read the introduction briefly, (d) looking for the important chapter and read some sentences, (e) read the conclusion of the book (if available) and (f) read the 
Journal on Language and Literature Vol. 6 No. 2 June 2020

references, index and appendix of the book.

The other type of cognitive strategy which was employed by all students in a high level is using resources for receiving messages strategy (I use English dictionary to translate the difficulties words in the text). It means that all the students need English dictionary in translating the difficult words or a dictionary always becomes the best solution in understanding a difficult text. This strategy is actually suggested or recommended by Jennings et al., (2006:261-2). They state that using dictionary will help students to be independence in learning about words. Moreover, it is not the best way for a student in learning English but dictionary also provides some advantages.

The dictionary gives students independence in learning word meanings: however, it should not be overused as an instructional tool. Even though the

dictionary is no the best way to develop words meaning, it does have many uses.

It provides definitions, offers a means to distinguish among definitions, gives

$a$

key for pronunciation, and supplies the different forms of a base word.(Jennings, at al. 2006:261-2)

Dictionary can be used to find out the meaning of what is read in the new language, or to produce messages in the new language. For better understanding about the materials that we read, printed resource such as dictionaries, word lists, grammar books, and phrase book may be valuable (Oxford, 1990:81). Moreover, encyclopaedias, travel guides, magazines, and general books on culture and history can provide useful background information. The problem is how to use dictionary it self. In this case, Blachowicz \& Ogle (2008:206) explain that students should learn and know hot to use a dictionary.

In translating English text, the high achiever students select sentence by 
Journal on Language and Literature Vol. 6 No. 2 June 2020

sentence translation strategy than word for word translation. The average of this item is (3.8) which was categorized in a high level while middle and low achiever students used sentence by sentence translation in a medium level (the average are 3.1 \& 2.1). It indicates that high achiever students preferred to employ sentence by sentence than word for word translation as one of the best way in understanding English text. It also reveals that translation strategy helps them in learning and interpreting the text and it was used as a basic knowledge in comprehending text. Oxford (1990) emphasizes that in trying to find the text meaning or comprehending an English text, translating can be a helpful strategy early in language learning, as long as it is used with care. It allows learners to use their own language as the basis for understanding of what they read in the new language (Oxford, 1990: 85).

Another argument about using translation comes from Nuttal (1996). Nuttal describes that translation is an activity that forces students to get grips with the text in the active way required for full comprehension (Nuttal, 1996:207). It means that translation strategy gives the students a guideline to get the text meaning or to understand the text comprehensively. From the explanation above, middle and low achiever students are recommended to employ this strategy because it is useful for reading English text as suggested Oxford (1990) and Nuttal (1996). In addition, middle and low achiever students should also consider employing sentence by sentence translation strategy as a way in comprehending a text.

Besides translation strategy, note-taking strategy also becomes an important reading strategy for high achiever students. It can be seen from their total average of mean in table 4.1 (3.5). It reveals that high achiever students always use note-taking to write the important information from the text. Middle achiever students used taking notes strategy in a medium level while low achiever students never or rarely (low level) employed taking notes strategy in comprehending a text.

The data above indicate that middle achiever students do not always take a 
Journal on Language and Literature Vol. 6 No. 2 June 2020

note about the significant information from the text while low achiever students rarely or never writing a note from a text that they read. It is contradictory with Oxford (1990:88) who states that taking notes is a very important strategy for reading. The focus of note taking should be on understanding and not writing.

Note-taking can be in the target language, thus involving writing practice. This strategy can also allow a mixture of the target language and the learners' own language, with known vocabulary words written in the target language and the rest in the native language. The effective of note taking procedures can do much to aid students in learning and retaining a vast amount of information (Tierney at all., 1980:55).

Note-taking also means to write the important information as stated by Wenden \& Rubin (1987:77) that note-taking is writing down the main idea, important points, outline, or summary of information presented orally or in writing. It also requires that students carefully record information in order to be able to cite their sources (Moreillon, 2007:12). In addition, Moreillon uses two differences terms in defining note taking (note-making/note taking) and emphasizes about the important of using note taking. It is stated that note making is to record information in one's own words and requires the learners pass information through their prior knowledge and experience and determine what is the important to record while note-taking is essential for recording quotes (Moreillon, 2007:157).

This finding is supported by the study which was conducted by Garnasih (2006) about reading strategies most frequently employed by the high and the low proficiency readers of third grade students of SMPN 4 Malang. It was found that the direct reading strategies most frequently employed by the high proficiency readers. Santiana (2009) investigated students' reading strategies and their reading comprehension at a Junior High School in Ciamis, West Java was found that the students used cognitive strategies most frequently when reading English text.

Some types of cognitive strategies used by high achiever students in 
medium level were: practice naturalistically (3.2), analyzing expression (2.8), reasoning deductively (3.4), summarizing (2.7), and highlighting (2.7). Those data indicate that students only sometimes read the authentic materials such as magazine and newspaper in English and divide the words into the part that they understand. Second, the data also shows that high achiever students do not always summarize and underline the important information that they read.

However, the middle achiever students employed analyzing expression (4.5), reasoning deductively (3.8), and highlighting (3.9) reading strategies in a high level. It shows that middle achiever students always divide words into parts that they understand, noticing the general rules used from the text and underlines the important information from the text while low achiever students used practice naturalistically, taking notes, and summarizing strategies into the low level. It displays that in reading English text, low achiever students rarely or never read authentic materials such as: news paper and magazine in English, and taking notes about the significant information and make summarizing from the text that they read.

Oxford (1990) defines practicing naturalistically strategy as using the language in an authentic way for reading comprehension (e.g. target language newspapers and magazines). In this case, teacher should encourage the lower achiever students to read authentic materials as a medium of reading practice and comprehension as suggested by Oxford (1990:80) "help students to practice their reading by giving them active and interesting reading tasks". Practice also refers to strategies which contribute to the storage and retrieval of language while focusing on accuracy of usage. Practice involves repetition, and experimentation, application of rules, imitation, and attention to detail (Wenden \& Rubin, 1987:24).

In addition, Oxford (1990:83) explains that analyzing expressions is often helpful to break down a new word, phrase, sentence, or even paragraph into its component parts some spoken in the new language. It will help students to understand the difficult words by diving into the parts that they understand. The words research could be divided into [re-search]. In reasoning deductively 
Journal on Language and Literature Vol. 6 No. 2 June 2020

strategy, students are proposed to read by paying attention to the general rules that the readers already know. It is a common and very useful type and logical thinking (Oxford, 1990:82). Wenden \& Rubin (1987:24) emphasize reasoning deductively as a problem-solving strategy in which the learner looks for and uses general rules in approaching the foreign or second language. In this case, the learner uses previously acquired linguistic or conceptual knowledge to get specific hypothesis about the linguistic form, semantic meaning or speaker's intention.

Summarizing strategy is the retelling of the important parts of a passage in a much shorter form (Mikulecky \& Jeffries, 1996:167). The objective of summarizing is to make sure that the readers have understood something, to explain the sense of a passage to someone else, to review text for examination. A good summary includes the main idea and major supporting points and does not include minor details, repeated details, or the reader's opinions. According to Oxford, writing a summary can be more challenging because it often requires greater condensation of thought (Oxford, 1990:88). The last strategy is using highlighting by supplementing notes. This strategy emphasizes the major points in a dramatic way, through colour, underlining, capital letters, initial capitals, big writing, bold writing or circle (Oxford, 1990: 89).

\section{c. Compensation Strategy}

Compensation strategy helps learners to overcome their knowledge gaps and continuing to communicative authentically (Oxford, 1990:8-9). It is also useful for more expert language user, who occasionally does not know an expression, who fails to hear something dearly, or who is faced with a situation in which the meaning is only implicit or intentionally vague.

The findings of this study explain that high achiever students employed compensation strategy in a have high level while the middle and low achiever students used it in a medium level. They use linguistic clues strategy (I guess the sentence meaning by noticing the linguistic clues such as suffixes, prefixes, or word order) was employed by high achiever students in a high level moreover the middle 
Journal on Language and Literature Vol. 6 No. 2 June 2020

and low achiever students used this strategy in a medium level. The high and middle achiever students employed using other clues strategy (I guess the text meaning through the text structure as fallows; title, introduction, summary, and conclusion) in a high level while the low achiever students employed it in a medium level.

The description above points out that high achiever students always guess the sentence meaning by noticing the linguistic clues such as: suffixes, prefixes, or word order when reading while middle and low achiever students did it in sometimes. The use of using linguistic clues strategy in reading is in line with Oxford (1990:92) who states that using linguistic clues is related to how to guess meaning and it is a good strategy for learner. The data above also indicate that high and middle achiever students always guess the text meaning by paying attention to the text structure as follows: introduction, summary, and conclusion.

In this case Oxford (1990) argues that an important source of clues to meaning is the text structure-that is, introductions, summaries, conclusions, titles, transitions, and ways of dividing the text.

In using other clues strategy, middle and low achiever students employed it in a medium level. It means that they only sometimes guess the meaning of sentence by noticing the suffixes, prefixes, or word order, and the text structure such as: title, introduction, summary, and conclusion when reading English text.

\section{d. Metacognitive Strategy}

Metacognitive strategy is a higher order executive skills that may entail planning for, monitoring, or evaluating the success of a language learning and applicable process to a variety of learning tasks (Brown et al., 1983; Nisbet et al., 1986, in O'Malley \& Chamot, 1990:44), it also includes having a purpose in mind, previewing the text as to its length and organization (Noor et al., 2009:139).

The data from questionnaires show that high and low achiever students 
Journal on Language and Literature Vol. 6 No. 2 June 2020

employed metacognitve strategy in a medium level while middle achiever students used it in a high level. Some types of metacognitive strategies which were employed in a high level are: setting goals and objective, identifying the purpose and language tasks, planning for a language task, seeking practice and opportunities, and self-monitoring strategies.

It indicates that high and middle achiever students only sometimes organized their learning by designing the language schedule for reading; low achiever students rarely or never design their reading schedule. Related to this reading problem, the next teaching program should be included the explanation about how to design a learning program. Oxford (1990:156) explains that organizing strategy includes a variety of tools, such as creating the best possible physical environment, scheduling well, and keeping a language learning notebook. Some techniques that might be used to help students in increasing their reading abilities as suggested by Oxford (1990) are as follows: (1) establish a good classroom environment, and encourage the students to create an appropriate setting for learning at home, (2) assist the students in developing practical weekly schedules for language learning, and (3) prepare a tool of language learning such as notebook.

The other strategies which were employed by high and middle achiever students as follows: setting goals and objective strategy (I have clear goal and objective for improving my reading skill) and identifying the purpose and language task (I determine the purpose of reading in light of situation and the type of material). The Low Achiever students employed those strategies in a medium level (sometimes). It indicates that establishing reading goals, objective and determining the purpose based on situation and materials assist the high and middle achiever students in understanding English text.

Oxford (1990) states that goals are generally consider being long-range aims referring to the outcome of many months or even years and objectives are short-term aims for hours, days, or weeks (Oxford, 1990:156).

The other argument which is emphasized about using setting goals and 
Journal on Language and Literature Vol. 6 No. 2 June 2020

objectives to improve the students' reading comprehension comes from Willis (2008). It is stated that the part of students' goal in reading includes finding information to support their prediction or to answer their question (Willis, 2008:133). The goals can also encourage them to monitor their comprehension, and stimulate active thinking or they read.

The use of identifying the purpose and language task strategy as the way in comprehending a text in a high level by high and middle achiever students indicates that in reading English texts, they always identify the purposes of their reading materials. It is in line with Hood et all. (1996:42) who state that one starting point when planning a reading program or lesson is to consider the goals or general purposes for which the students are learning to read. In addition, this strategy involves determining the task purpose - an act useful for all language skills. The strategy of considering the purpose is an important one because knowing the purpose for doing something enables learners to channel their energy in the right direction (Oxford, 1990:159). For the low achiever students, those strategies must be employed as a solution strategy in understanding English text.

The data also show that all the students employed planning for a language task strategy. It means that identify the nature of the text and use specific requirement to comprehend the text such as a dictionary enable and help them in understanding a text. It also displays that most of the students were interested in employing this strategy. It is related to Oxford (1990) who describes that the planning involves devising solution method and carrying out the steps to create the actual solution for a giving problem. Regardless of the language skill(s) involved, this strategy always involves identifying the general nature of the task, the specific requirements of the task, the resources available within the learner, and the need for further aids (Oxford, 1990: 159).

The high achiever students used seeking practice opportunities strategy in a high level which means that every high achiever students always look for the opportunities for reading as much as possible. The middle and low achiever students used this strategy in a medium level or they only sometimes try to find out the 
OUmanitatis

Journal on Language and Literature Vol. 6 No. 2 June 2020

opportunities to read as much as possible. The use of this strategy indicates students' responsibilities in designing their own reading schedule. Oxford (1990:160) argues that seeking opportunities strategy underscores students' responsibility to generate their own opportunities to practice.

All students employed self-monitoring reading strategy in a high level. It indicates that students always evaluate their reading comprehension progress and monitor their reading abilities. The use of this strategy also shows that selfmonitoring add students' knowledge and enable them to monitor/evaluate their errors and mistakes. Blachowicz \& Ogle (2008) describe the activities of using self-monitoring strategy as follows:

Students learn more about something, they add to their knowledge, refined their own predictions, tried to clarify what they were thinking, and changed their thinking when necessary. When a book is confusing, they worked

together to figure out what the author was saying; they would sometime back up, reread, or look for other information. They would ask their teacher or another student for help. They got totally stuck or would check out their thinking with other media (Blachowicz \& Ogle, 2008:36)

It is in line with Oxford (1990) and Willis (2000) who state that self-monitoring does not centre as much on using the language as it does on students' conscious decision to monitor - that is, notice and correct - their own errors in any of the language skills (Oxford, 1990:161). This strategy requires students to learn stop periodically to take notes of the words they do not understand or parts of the plot that do not make sense (Willis, 2008:138).

The last strategy in metacognitive is self-evaluating strategy. Although some expertises have recommended that self-evaluating is a significant reading strategy but the data indicate that high and low achiever students rarely or never used it. It reveals that the students do not always employ all reading 
Journal on Language and Literature Vol. 6 No. 2 June 2020

strategies to understand a text. The middle achiever students employed this strategy in a medium level. Blchowicz \& Ogle (2008) emphasize that selfevaluation enables the students more active as a learner; look at that they know and what are guiding their learning at the beginning of a unit project (Blchowicz \& Ogle, 2008: 252). This strategy may consist learners' assessing their proficiency in a variety of ways. They might estimate whether their reading skills have improved since the last check. They might consider what proportion of a reading passage they understand, and whether this represents any sign of progress (Oxford, 1990:162).

\section{CONCLUSION}

The final product of the materials consists of a course material of Life Skill Based English Material and a teacher's manual. Whole Language Reading provides rich input of reading strategies, variety of topics, concepts, texts, activities, tasks, and evaluations. Using this material makes reading more holistic and meaningful as it provides integration across language skills and subject areas.

\section{REFERENCES}

Alhaddad, A.S. 2014. Jordanian literacy education: Should whole language be implemented?. European Scientific.

Berkeley: RDR Books. Harwood, Nigel. 2010. English language teaching materials: Theory and practice. Cambridge: Cambridge University

Brolin, D.E. 1989. Life Centered Career Education: A Competency Based Approach. Reston, VA: The Council for Exceptional Children.

B. \& Hitomi, M. 2010. Published research on materials development for language learning. In Tomlinson, B., \& Masuhara, H. (Eds.), Research for materials development in language learning: Evidence for best practice. New York: Continuum International Publishing Group.

Borg W. R., \& Meredith D. G. 1983. Educational research: An introduction. New York: Longman Inc. 
Bravos, Kalli. 2010. Readability tests and formulas. Retrieved from http://www.ideosity.com/ 2010/01/14/readability- tests-and-formulas

Brown, H. D. 2007. Teaching by principles: An integrative approach to language pedagogy. New York: Pearson

Cypress: Creative Teaching Press, Inc. Gall, Meredith D., Joyce P. G, \& Walter R. B. 2007. Educational research: An introduction. Boston: Pearson

Depdiknas. 2002. Pendidikan Berorientasi Kecakapan Hidup (Life Skill) Melalui Pendekatan Broad-Besed Education. Jakarta: Departemen Pendidikan Nasional.

Dubin, Fraida and Elite Olstain. 1986. Course design. Developing Programs and Materials for Language Learning. Cambridge: Cambridge University

Education, Inc. Goodman, K. 2005. What's whole in whole language: 20th anniversary edition.

Education, Inc. Dick, W., Lou, C., \& James, O.C. 2009. The systematic design of instruction. New Jersey: Pearson Education Upper

Graves, Kathleen. 2000. Designing Language Course: A Guide for Teachers. London: Heinle\&Heinle Publisher.

Handayani, sri. 2009. Muatan life skills dalam pembelajaran di sekolah: upaya menciptakan sumber daya manusia yang bermutu. Presented in International Education Conference, UPI - UPSI, Malaysia. Universitas Pendidikan Indonesia.

Hedgcock, J. S., \& Dana, R. F. 2009. Teaching readers of English: students, texts, and contexts. New York:

McDonough, J., \& Christopher, S. 2005. Materials and methods in ELT: A teacher's guide. Malden: Blackwell Publishing.

Moghadam, J.N. 2011. The importance of whole language approach in teaching English to intermediate Iranian EFL learners. Theory and Practice in Language Studies, 1(11), 1643-1654.

Masitoh, Dewi, Permasih. 2000. Studi Implementasi Kurikulum Berbasis Kecakapan Hidup (Life Skill) pada Jenjang Sekolah Dasar. Jurnal Penelitian Vol.10 No.2 Oktober 2009 
Nation, I.S.P. 2009. Teaching ESL/EFL reading and writing. New York: Routledge, Taylor \& Francis Group. Qiang, N, Martin, W., \& Teng, H. (2008). China EFL: A new paradigm. Education in China: 21st century issues and challenges. New York: Nova Science Publishers.

Richards, Jack C. 2005. Curriculum development in language teaching. Cambridge: Cambridge University Press.

Richards, Jack.C and Theodore S. Rodgers. 2001. Approaches and Method in Language Teaching. Cambridge: Cambridge University press.

Richard, Jack. C and Willy A. Renandya. 2002. Methodology in Language Teaching: An Anthology of Current Practice. Cambridge. Cambridge University Press.

Routman, R. 1991. Invitations. Toronto: Irwin Publishing.

Sidek, Horison Mohd. 2012. EFL reading instruction: Communicative task-based approach. International Journal of Instruction, 5(2), 109-110.

Taylor, M. 2007. Whole language teaching is wholehearted activism. In Monica Taylor (Ed.), Whole language teaching, whole-hearted practice: Looking back, looking forward. New York: Peter Lang Publishers, Inc. Tomlinson,

Routledge, Taylor \& Francis. Jolly, D., \& Rod, B. 2011. A framework for materials writing. In Brian Tomlinson (Ed.), Materials development in language teaching. Cambridge: Cambridge University Press.

Selinger, Herbert and ElanaShohamy. 1989. Second Language Research Methods. Oxford. Oxford University

Saddle River. Eisele, B. 1991. Managing the whole language classroom: A complete teaching resource guide for $\mathrm{K}-6$ teachers.

Tomlinson, B. 2000. Materials evaluation. In Tomlinson, B. (Ed.) Developing materials for language teaching. New York: Continuum.

Wang, P. 2011. The effect of computer-assisted whole language instruction on Taiwanese university students' English learning. English Language Teaching, 4(4), 10-20.

Weaver, C. 1990. Understanding whole language from principles to practice. Toronto: Irwin Publishing. 